\title{
"Aporte del Postgrado en Ingeniería Electrónica en la formación de investigadores"
}

La Universidad del Cono Sur de la Américas (UCSA) fiel a su misión orientada a la investigación y la innovación ha iniciado en febrero de 2019 su primer programa de posgrado denominado "Maestría en Ingeniería Electrónica, con énfasis en energías renovables y eficiencia energética" (UCSA, 2018). El mencionado posgrado obtuvo la financiación del Consejo Nacional de Ciencia y Tecnología (CONACYT) mediante el Programa de Apoyo a la Formación de Docentes-Investigadores, Convocatoria 2017 (CONACYT, 2018). En ese contexto, el CONACYT promueve el fortalecimiento de las capacidades nacionales para la investigación científica y el desarrollo tecnológico nacional.

Por tanto, la maestría en Ingeniería Electrónica tiene como objetivo formar una masa crítica de docentes investigadores, capaces de generar conocimiento científico dentro del ámbito de la Investigación, Desarrollo e Innovación $(\mathrm{I}+\mathrm{D}+\mathrm{i})$, basado en sólidos fundamentos teórico-experimentales para el desarrollo de la innovación en el área de las energías renovables y la eficiencia energética. Para lograr el objetivo, el proyecto académico cuenta con docentes altamente calificados especializados en las distintas áreas de las energías renovables y la eficiencia energética provenientes de España, Chile, Canadá y Paraguay.

Desde el punto de vista de la formación de investigadores, el programa prevé la elaboración de artículos científicos en el marco de los Trabajos Finales de Maestría que serán enviados para su publicación y presentación en conferencias internacionales de reconocido prestigio. Por otro lado, los estudiantes también tendrán una participación activa en proyectos de investigación de manera que puedan vincular lo aprendido con las necesidades del Paraguay en el ámbito energético. Todo esto constituye un hito desde el punto de vista de la formación altamente calificada en investigación, tanto para la UCSA como para el país.

Por otro lado, desde un punto de vista contemporáneo, regional y local, el programa de postgrado se centrará en el empleo de las energías renovables no convencionales tales como la energía eólica y la energía solar fotovoltaica. En ese contexto, la ingeniería electrónica juega un rol vital mediante los convertidores electrónicos de potencia, quienes cumplen la función de garantizar la máxima entrega de la energía generada a partir de fuentes de energías renovables. Consecuentemente, estos nuevos conocimientos generados ayudarían a potencias el uso de las fuentes de energías renovables en el país, el cual hasta la fecha se encuentra centrada en las hidroeléctricas y en la biomasa.

Prof. Jorge Rodas, Ph.D. Coordinador de la Maestría en Ingeniería Electrónica Universidad del Cono Sur de las Américas (UCSA) https://sites.google.com/view/jorgerodas/ https://sites.google.com/view/mie-ucsa 


\section{REFERENCIAS BIBLIOGRÁFICAS}

CONACYT (2018). Maestría en Ingeniería Electrónica con énfasis en Energías Renovables y Eficiencia Energética, de la Universidad del Cono Sur de las Américas (UCSA). Disponible en: http://www.conacyt.gov.py/CONACYT-informa-aperturaconvocatoria-Maestria-Ingenieria-Electronica

UCSA (2018). Maestría en Ingeniería Electrónica. Disponible en: https://sites.google.com/view/mie-ucsa

\section{"Contribution of the Postgraduate in Electronic Engineering in the training of researchers"}

The University of the Southern Cone of the Americas (UCSA) faithful to its mission-oriented to research and innovation has initiated in February 2019 its first graduate program called "Master in Electronic Engineering, with emphasis on renewable energy and energy efficiency." The aforementioned postgraduate program obtained funding from the National Council of Science and Technology (CONACYT) through the Support Program for Teacher-Researcher Training, Call 2017. In this context, CONACYT promotes the strengthening of national capacities for scientific research and national technological development.

Therefore, the Master in Electronic Engineering aims to form a critical mass of researchers, capable of generating scientific knowledge within the field of Research, Development, and Innovation $(R+D+i)$, based on sound theoreticalexperimental foundations for the development of innovation in the area of renewable energy and energy efficiency. To achieve this objective, the academic project has highly qualified teachers specialized in the different areas of renewable energy and energy efficiency from Spain, Chile, Canada, and Paraguay.

From the point of view of the training of researchers, the program provides for the preparation of scientific articles within the framework of the Master's Final Works that will be sent for publication and presentation at international conferences of recognized prestige. On the other hand, students will also have active participation in research projects so that they can link what they have learned with the needs of Paraguay in the energy field. All this constitutes a milestone from the point of view of highly qualified training in research, both for UCSA and for the country.

On the other hand, from a contemporary, regional and local point of view, the postgraduate program will focus on the use of non-conventional renewable energies such as wind energy and photovoltaic solar energy. In this context, electronic engineering plays a vital role through electronic power converters, which fulfill the function of guaranteeing the maximum delivery of energy generated from renewable energy sources. Consequently, the new knowledge generated would help power the use of renewable energy sources in the country, which to date is focused on hydroelectric and biomass. 